\title{
Apple and oranges: Comparison of Taiwan higher education institutions' internationalization
}

Chin, Joseph Meng-Chun

National Chengchi University, Taiwan, ROC (mcchin@nccu.edu.tw)

$\mathrm{Wu}$, Cheng-Ta

National Chengchi University, Taiwan, ROC (chengta@nccu.edu.tw)

Ching, Gregory S.

Lunghwa University of Science and Technology, Taiwan, ROC (gregory ching@yahoo.com)

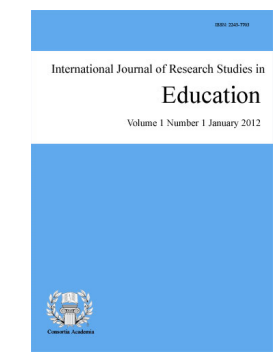

ISSN: 2243-7703 Online ISSN: 2243-7711

OPEN ACCESS

Received: 1 November $2011 \quad$ Revised: 2 January $2012 \quad$ Accepted: 10 January 2012

Available Online: 25 January 2012 DOI: $10.5861 /$ ijrse.2012.v1i2.24

\section{Abstract}

The internationalization of higher education has become more obvious during the last decade. With the world becoming more globalized, competitions among higher education institutions (HEIs) are not limited to the local arena, but have expanded overseas. In Taiwan, the recent rise in numbers of HEIs has further strengthened the need for institutions to compete between each other. Hence, in order become competitive, HEIs in Taiwan have taken great measures to become internationalized. This mixed-method study presents an examination of the internationalization efforts of HEIs in Taiwan with a goal of measuring their actual degree of internationalization using the twelve (12) internationalization indicators proposed by Chin and Ching (2009). Participants are the 164 HEIs in Taiwan. A total 34 HEIs participated in the study. Survey questionnaire and interview were conducted. Results show that trend in internationalization has triggered drastic change both in the administration and the orientation of HEIs. This inevitably forces HEIs either to conform to the mainstream or to remain within their comfort zone. Findings also shed light to the different internationalization strategies of Taiwanese HEIs and shall serve as a point of reference for contemporary visions of the internationalization exemplar in the age of globalization.

Keywords: internationalization; globalization; mixed-method study; performance assessment; internationalization indicators 


\section{Apple and oranges: Comparison of Taiwan higher education institutions' internationalization}

\section{Introduction}

Higher education systems throughout the world have recently undergone significant restructuring processes to enhance institutional competitiveness and hierarchical positioning within their own countries (Mok, Deem, \& Lucas, 2008). These issues have become even more evident with the rise of higher education institutions (HEIs) rankings throughout the world. Higher education experts acknowledge that global capital has invested heavily in knowledge industries worldwide, including higher education and advanced training (Altbach \& Knight, 2007). This situation also applies to East Asia; during the past decades, Taiwan has undergone dramatic changes in its higher education system (Mok, 2006; Song \& Tai, 2007). Since martial law was lifted in 1987, Taiwan's educational system has entered an era of transition and reform by shifting from an industrial, labor-intensive structure to a capital and technological based, political democratization structure (Chou \& Ho, 2007).

Parallel to the issues of globalization and internationalization, HEIs are also simultaneously faced with challenges of accountability, value adding, and transparency (Kingsbury, 2007). These challenges, together with rising concerns about the value of money against the high cost of educational goods, have altogether changed the way higher education is governed (Welch, 2004). Similarly, pressure to compete internationally and the quest to attain global recognition have also become major benchmarks in evaluating university performance (Mok, 2003; Song \& Tai, 2007). With the international dimension of higher education becoming an intense topic interest and debate, new realities facing the higher education sector, both domestically and globally are presenting changes, introducing new trends and posing different challenges for internationalization.

This mixed-method study presents an examination of the internationalization efforts of HEIs in Taiwan with a goal of measuring their actual degree of internationalization using the twelve (12) internationalization indicators proposed by Chin and Ching (2009) namely: institutional commitments, strategic planning, funding, institutional policy and guidelines, organizational infrastructure and resources, academic offerings and curriculum, performance evaluation and accountability, internet presence, faculty and faculty development, international students and scholars, study abroad, and campus life. The following sections shall review the guiding ideas of the twelve internationalization indicators. A description of the research process is provided in a subsequent section which leads into an outline of the methodological framework. Next, a summary of the statistical analyses is provided along with a discussion of the results. A concluding discussion offers insights and implications regarding the different internationalization strategies of Taiwanese HEIs shall also be given.

\section{Internationalization indicators}

Chin and Ching (2009) proposed twelve indicators that could be used to measure Taiwan's HEIs. These indicators are the synthesized findings from the 37 reviewed internationalization related studies, combined with the results from the individual interviews with foreign internationalization experts, local campus internationalization officers, and international students in Taiwan. Table 1 shows a summary of the twelve indicators. Their study presents an initial attempt in trying to establish a set of performance indicators to measure Taiwan HEIs internationalization. In responds to their call for further actual application of the proposed indicators, the current study shall attempt to measure the internationalization of HEIs in Taiwan.

\section{Methodology}

The research was designed as a mixed method study. Methodology from both qualitative and quantitative paradigms were systematically combined in an attempt to enhance the strengths of data collection and advance 
Apple and oranges: Comparison of Taiwan higher education institutions' internationalization

insights surrounding the internationalization of Taiwan's HEIs (Axinn, Fricke, \& Thornton, 1991; Johnson \& Christensen, 2008). The main objective of this research is to measure Taiwan's HEIs internationalization. In order to further understand the extent of HEIs internationalization, an analysis of all the 164 HEIs was first conducted. To date there is a total of 164 HEIs in Taiwan, of which 34\% (55) are national or government operated; the rest (66\% or 109) are private institutions (MOE, 2008b). Of the 164 institutions, approximately $57 \%$ or 94 institutions are technical or vocational colleges; these institutions offer courses in areas such as agriculture, industry, business, maritime studies, marine products, medicine, nursing, home economics, drama, and art (MOE, 2008a). Approximately 38\% or 62 of the 164 HEIs are typical universities or colleges; these institutions offer typical undergraduate programs requiring four years of study and specialized undergraduate programs such as dentistry or medicine which require six to seven years of study, including an internship period of one year (MOE, 2008b). The remaining $5 \%$ or 8 institutions are normal colleges; these institutions specialize in teacher education and training (MOE, 2008b).

\section{Table 1}

Taiwan's HEIs internationalization indicators

Internationalization indicators

Institutional Commitments

Strategic Planning

Funding

Institutional Policy and Guidelines

Organizational Infrastructure and Resources

Academic Offerings and

Curriculum

Internet Presence

Faculty and Staff Development

International Students and

Scholars

Study Abroad

Campus Life

Performance Evaluation and Accountability
Summarized contents

Articulated commitments on internationalization efforts; inclusion in the mission/vision, goals and objectives; promotion; membership in local/international academic organizations

Long term and short term plans for institution, department, faculty, and student levels; internationalization timeline; plan to establish branches; partners with private, public, local, international, academic, and industry Seeks funding from various organizations, government, and other private entities

Faculty policies and guidelines regarding hiring, rewards, sanctions, code of conducts; student policies and guidelines regarding admission, rewards, sanctions, opportunities

Availability of an internationalization supporting system including office, professionals and staff, resources

Foreign language requirements; availability of professional language courses; internationalized curriculum development

Links to international liaison office or foreign student admission; bilingual information regarding important dates, fees, and news; clear information on requirements together with programs and course offerings; need to know links

Provision of support for collaboration, research, conferences, and other internationalization efforts

Scholarships, housing, offices, facilities and other support systems; student and language partner/buddy program

Academic/non-academic travels; travel subsidies; orientation; symposia for incoming and outgoing students

Presence of campus life office and officer; organizations with internationalized theme; formal/informal academic /extra-curricular international activities

Performance and monitoring system indicators; internal/external reviews; reporting, recommendations, research and studies in internationalization efforts

Source. (Chin \& Ching, 2009, p. 196 \& 198) 
In order to have detailed information of Taiwan's HEIs internationalization, this research's main participants are the internationalization officers of each HEI in Taiwan. A total of 164 survey questionnaires were sent out (one survey questionnaire to each HEI). The survey questionnaires were addressed to the institution's international affairs centers or offices. However, for those institutions that does not have an official international affairs office, the survey questionnaires were sent to their research and development (R\&D) division, the admissions department or campus liaison offices. Results gathered from the survey questionnaire was then encoded and analyzed using the Statistics Package for Social Science (SPSS) version 15. Descriptive statistics was accomplished, wherein the mean, standard deviation (SD) and percentage of the respondents' selection are tabulated, analyzed, and conclusion drawn.

The survey questionnaires stage resulted in the collection of 34 HEIs data. However, the 34 responding HEIs only represented $21 \%$ of the total HEIs in Taiwan. Hence, the result of this research shall be limited to the information given by the 34 HEIs. Table 2 shows that of the 34 respondents around $44 \%$ or 15 institutions are government owned public HEIs and around $56 \%$ or 19 institutions are privately owned HEIs. Table 2 also shows that 19 or $56 \%$ are typical institutions, 3 or $9 \%$ are normal colleges, and 12 or $35 \%$ are technical vocational institutions. In addition, 6 or 18\% of the respondents are schools which are included in the Project to Develop First-Class International University Research Centers; these are selected HEIs that are awarded with funds to assist in the improvement of their overall international competitiveness (MOE, 2006b).

Table 2 also shows that 28 or $82 \%$ of the responding institutions have foreign or international students enrolled in their campus, while 27 or $79 \%$ have foreign or international faculties teaching in their campus. In addition, all of the responding institutions claimed that they have some course programs that are internationalized and the existence of international partner schools (sister schools) through the signing of memorandum of understanding (MOU)s and memorandum of agreements (MOA)s, while all but one of the responding institutions have foreign language courses availability.

Further analysis of the respondents reveals that the 15 government owned public HEI respondents represents around $27 \%$ of the total 55 government owned public HEIs in Taiwan. While the 19 privately owned HEI respondents represents around $17 \%$ of the total 109 privately owned HEIs in Taiwan. Similarly, Table 2 also reveals that 19 of the typical institutions represent around $31 \%$ of the total 62 of the typical institutions in Taiwan. While the 3 normal institutions represent around $38 \%$ of the total 8 normal institutions in Taiwan and the 12 technical vocational institutions represent around $13 \%$ of the 94 technical vocational institutions in Taiwan. Lastly, table 2 also reveals that 6 of the HEIs who are included in the Project to Develop First-Class International University Research Centers represent around 55\% of the total 11 member HEIs. These imply that the 34 responding HEIs do represent all the different types and class of HEIs in Taiwan.

In order to gather additional information regarding the internationalization of Taiwan's HEIs, an interview request was sent to all the 34 responding HEIs in the prior stage. Among the 34 HEIs, a total of 22 internationalization officers responded. The local internationalization officer respondents have an average of 3.36 years of experience in the internationalization efforts of their institutions. Around $41 \%$ or 9 of them are working in a government owned HEI, while $59 \%$ or 13 are working in the private sector. In addition, $23 \%$ or 5 of the respondents are working in schools which are included in the Project to Develop First-Class International University Research Centers. Core question on what factors and strategies are involved in the internationalization of Taiwan's HEIs are asked and discussed. The insights from the respondents are then coded and categorized into major trends by seeking common key words and phrases (Miles \& Huberman, 1994). Lastly, the results of the analysis were then organized together with all the relevant information which culminated into the conclusions and recommendations of the study.

\section{Results and discussions}

The survey questionnaires stage resulted in the collection of 34 HEIs data. Even though that the 34 
Apple and oranges: Comparison of Taiwan higher education institutions' internationalization

responding HEIs only represented $21 \%$ of the total HEIs in Taiwan, however, upon further analysis the 34 responding institution represents a variety of HEIs groupings. When asked how important is internationalization to their institution? Table 3 shows that 24 or $71 \%$ mentioned that institutional internationalization is one of their top priorities; similarly, it also shows that around 7 or $21 \%$ of the responding institution mentioned that they considered institutional internationalization as moderately important, while the remaining 3 or $8 \%$ claimed that internationalization is their lowest priority.

\section{Table 2}

Survey questionnaire respondent's profile $(N=34)$

\begin{tabular}{|c|c|c|c|c|}
\hline \multirow[t]{2}{*}{ Items } & \multicolumn{2}{|c|}{ Respondents } & \multicolumn{2}{|c|}{ Population } \\
\hline & $n$ & $\%$ & $N$ & $\%$ \\
\hline \multicolumn{5}{|l|}{ Ownership } \\
\hline National (government/public) & 15 & 44 & 55 & 27 \\
\hline Private & 19 & 56 & 109 & 17 \\
\hline \multicolumn{5}{|l|}{ Institution type } \\
\hline Typical & 19 & 56 & 62 & 31 \\
\hline Normal college & 3 & 9 & 8 & 38 \\
\hline Technical/vocational college & 12 & 35 & 94 & 13 \\
\hline \multicolumn{5}{|c|}{ Included in the Project to Develop First-Class International University Research Centers ${ }^{\mathrm{a}}$} \\
\hline Yes & 6 & 18 & 11 & 55 \\
\hline No & 28 & 82 & 153 & 18 \\
\hline \multicolumn{5}{|l|}{ International students } \\
\hline Yes & 28 & 82 & 113 & 25 \\
\hline No & 6 & 18 & 51 & 12 \\
\hline \multicolumn{5}{|l|}{ International faculty } \\
\hline Yes & 27 & 79 & 128 & 21 \\
\hline No & 7 & 21 & 36 & 19 \\
\hline \multicolumn{5}{|l|}{ Internationalized curriculum programs } \\
\hline Yes & 34 & 100 & 161 & 21 \\
\hline No & 0 & 0 & 3 & 0 \\
\hline \multicolumn{5}{|l|}{ Foreign language programs } \\
\hline Yes & 33 & 97 & 151 & 22 \\
\hline No & 1 & 3 & 13 & 8 \\
\hline \multicolumn{5}{|c|}{ International school partners (sister schools) } \\
\hline Yes & 34 & 100 & 163 & 21 \\
\hline No & 0 & 0 & 1 & 0 \\
\hline
\end{tabular}

Source: Taiwan's HEIs websites (as of May 2011)

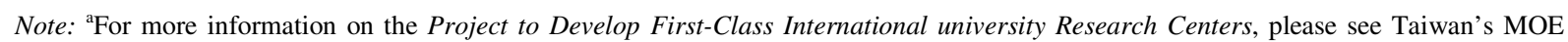
Website. (http://english.moe.gov.tw/ct.asp?xItem=7131\&ctNode=505\&mp=1)

Further analysis of the result reveals that there is a positive correlation between the institutions' importance of internationalization and their internationalization efforts with $\mathrm{r}(34)=0.405, p<0.05$ (for more details, please refer to table 4). These results suggest that HEIs who considers internationalization as a top priority will most likely establish a department or division specifically to handle the internationalization efforts of the institution. Similarly, this factor also holds true to HEIs who are included in the Project to Develop First-Class International University Research Centers. This also coincides with interview results from the local internationalization officers. 
Actually, the school places much importance on the internationalization efforts of the institution. Just recently, the school decided to upgrade the international education exchange center into the Office of International Cooperation (OIC), which is a department level division of the institution. Having these changes, the OIC will now have more staffs and funding to further pursue the institution's internationalization (L-INT5).

Table 3

Importance of internationalization $(N=34)$

\begin{tabular}{|c|c|c|c|c|}
\hline \multirow[t]{2}{*}{ Items } & \multicolumn{2}{|c|}{ Respondents } & \multicolumn{2}{|c|}{ Population } \\
\hline & $n$ & $\%$ & $N$ & $\%$ \\
\hline \multicolumn{5}{|l|}{ Importance of internationalization } \\
\hline Top priority & 24 & 71 & & \\
\hline Moderate priority & 7 & 21 & & \\
\hline Lowest priority & 3 & 8 & & \\
\hline \multicolumn{5}{|l|}{ Internationalization efforts } \\
\hline International affairs department/center ${ }^{\mathrm{a}}$ & 12 & 35 & 47 & 26 \\
\hline International office/group $^{b}$ & 22 & 65 & 83 & 27 \\
\hline None $^{\mathrm{c}}$ & 0 & 0 & 34 & 0 \\
\hline
\end{tabular}

Source: Taiwan's HEIs websites (as of May 2011)

Note: ${ }^{\mathrm{a}} \mathrm{A}$ department or division of the institution whose main purpose is to support the internationalization efforts of the institution. ${ }^{\mathrm{b}} \mathrm{A}$ small group of people or some designated persons whose main task is to support the internationalization efforts of the institution. ${ }^{\mathrm{c}}$ Internationalization efforts of the institutions are channeled through other personnel departments.

\section{Table 4}

Correlation between the respondents' importance of internationalization and internationalization efforts $(N=$ 34)

\begin{tabular}{llll}
\hline \multicolumn{1}{c}{ Items } & Mean & $S D$ & $r$ \\
\hline Importance of internationalization & 1.38 & 0.65 & \\
Internationalization efforts & 2.09 & 0.90 & $0.405^{*}$ \\
\hline
\end{tabular}

Note: $* p<0.05$

\subsection{Institutional Commitments}

Institutional commitments are articulated dedications to internationalization efforts, such as inclusion in the mission and vision statements, school objectives, and reiteration in the institution's prospectus or student recruitment literature (Green, 2005; Green, Luu, \& Burris, 2008). This also indicates the support provided by top administrative leadership, which is critical to the success of the institution's internationalization efforts (Davies, 1995, 1997; Ellingboe, 1998; Neave, 1992a, 1992b). In addition, the institution's efforts to join HEI organizations, whether locally or internationally are also included.

Results show that 29 or $85 \%$ of the responding HEIs mentioned that having membership in national HEI 
Apple and oranges: Comparison of Taiwan higher education institutions' internationalization

organizations as the most common activity for HEIs in Taiwan. Being a member in HEI organizations actually helps in achieving internationalization; collaborative internationalized activities such faculty and student exchange, research partnerships, and international conferences are some of the frequent undertakings of HEI organizations (Marden \& Engerman, 1992; Shutina, 2008). Another common item is the university president mentions international education in speeches with 26 or $77 \%$ of the responding HEIs agreeing. Institutional leadership is by far one of the most important factors in internationalizing HEIs (Neubauer, 2007). In addition, the frequent reiteration of issues regarding internationalization efforts by top HEI administrators affirms the institutions' commitment to internationalization (Ellingboe, 1998; Neave, 1992a, 1992b; Paige, 2003).

What I really tell is that internationalization is indeed an important issue in our school. In most of the activities that we organized (international affairs department), surely there will be someone from the top ranking officers of the school gracing the occasion. Besides these the school president always includes the issue of internationalization in his speeches, hence, I can tell that he too shares the vision of internationalization (L-INT6).

In addition, the items mission statement specifically refer to internationalization and institutional funding for international activities, staff, and offices both are found in 25 or $74 \%$ of the responding HEIs. In the literatures regarding internationalization, the presence of such factors are typically used to measure and distinguish highly internationalized HEIs from other, less internationalized HEIs (Green, 2005; Green et al., 2008; Green \& Olson, 2003).

\subsection{Strategic Planning}

Strategic planning is the long term and short term plans for internationalization at the institution, department, faculty, and student levels. This also includes an internationalization timeline, which highlights plans such as establishing branches and seeking partnerships with both the academic community and private industry. Internationalization scholars all claimed that a good strategic plan is an indispensable part of internationalization (Paige, 2005). However, more importantly institutional strategic plans should be based on the institution's mission vision, goals, or objectives. The institutional strategic plans should also serve as a rallying standard internally and simultaneously served as an indicator of the institution's intentions to its external constituencies (Davies, 1995, 1997).

Results show that the item international academic partners, which is the plan to have sisters schools by signing MOUs and MOAs is found in 31 or $91 \%$ of the responding HEIs. This is then followed by the item government sector partnership (local or foreign) with 29 or $85 \%$ of the HEIs agreeing. However, further interviews revealed that most Taiwan HEIs partners with local government entities.

With regards to the projects in partnership with government offices, in our school most professors have National Science Council (NSC) sponsored projects. I believe this is a kind of collaboration or partnership with the government sector. Similarly, the MOE and other government departments such as Ministry of Finance and many others, usually sponsors projects or studies related to their undertakings (L-INT8).

In addition, results also show that the items the plan provides budget resources for international activities and the plan lists specific internationalization activities for the university both are common to 28 or $82 \%$ of the responding HEIs. These are quite important for HEIs planning to become internationalized. Neave (1992a, 1992b) mentioned that both the administrative structures and strategies planning are crucial to successful institutional internationalization. These are then followed by the items the plan sets international education goals for the university and the plan sets for periodic internal and external performance evaluation both are common to 27 or $79 \%$ of the responding HEIs.

Looking at the least common item in institutional planning; the items the plan lists specific 
internationalization activities for faculties and departments, which is only common in 7 or $21 \%$ of the responding HEIs, indicates that internationalization in Taiwan's HEIs are mostly concentrated in the university levels. Evidently, most of the coordination of exchange programs is in the university levels. However, a large amount of student exchange programs are in collaboration with the institutions' department such as the Department of Business and Foreign Language Departments, which are clear indications of internationalization (Daly \& Barker, 2005; Paige, 2003). Lastly, the item plan to establish foreign branches is the least common with 3 or $9 \%$ of the responding HEIs agrees. This clearly suggest that Taiwan's HEIs are more focused on in-country development than venturing in another country, however, the result implies that the item plan to establish foreign branches is being considered by some HEIs.

\subsection{Funding}

Funding represents the effort that institutions put forth to seek funds specifically earmarked for internationalization activities from organizations, government, and other private entities. Obviously, as public funding decreases and the cost of higher education increases, funding higher education continues to be a growing concern around the world (HEDDA, 2007; Mok \& Tan, 2004). Kelo (2008) mentioned that for the coming decade higher education will be concern with issues regarding student mobility, alternative delivery of international education, funding of higher education, and the impact of labor market changes on higher education. In essence, much concern will be on funding and internationalization efforts of HEIs (Hayward, 2000; Siaya \& Hayward, 2003).

Results show that around 9 or $27 \%$ of the responding HEIs receive funds from private foundations, corporations, and/or alumni, while 5 or $15 \%$ of the responding HEIs mentioned that they receive funds from foreign international sources. Similarly, around 15 or $44 \%$ of the responding HEIs mentioned that they actively seeks fund specifically earmarked for internationalization efforts. With the current global economic situation, the cost of education abroad (study abroad/student exchange programs), is one of the major reasons students cite for not joining (Chen, 2007). Hence, the reasons why HEIs are actively taking part in assisting both the incoming and outgoing students in the exchanges (Ko, 2008; MOE, 2006a).

In addition, results also show that around 20 or $59 \%$ of the responding HEIs receives funding from the government. Taiwan's MOE has long been viewing international academic and cultural exchanges as effective ways for promoting understanding of peoples of different nations. The MOE considers these opportunities helpful in cultivating education, which serves as the foundation of any nation, and in producing educated individuals, who make up the cornerstone of national development (MOE, 2006a). Taiwan's MOE have actively sponsored programs for foreign students coming to Taiwan and Taiwanese students going abroad - for cultural exchanges and for learning with a focus on one of four different areas, which include visiting schools, providing services, gaining experience and obtaining skills (Lu, 2003).

\subsection{Institutional Policy and Guidelines}

Institutional policy and guidelines includes faculty policies and guidelines regarding hiring, rewards, sanctions, and codes of conduct. This also includes student policies and guidelines regarding admission, rewards, sanctions, and opportunities. The focus of institutional policy and guidelines is to ensure equality with regards to opportunity and benefits among local and international students and scholars alike. In addition, several large studies by the IAU mentioned several important indicators such as organizational support systems and institutional policies that deemed important indicators in the internationalization of HEIs (Knight, 2003, 2005, 2006a).

Results show that the item recognition of international degrees and credit is common in 27 or $79 \%$ of the responding HEIs. This is actually related to the item seek ways to certify local courses for international accreditation, which is common in 26 or $77 \%$ of the responding HEIs. In addition, these two items are highly 
Apple and oranges: Comparison of Taiwan higher education institutions' internationalization correlated with $\mathrm{r}(34)=0.918, p<0.01$ (for more details, please refer to table 5).

\section{Table 5}

Correlation between the items recognition of international degrees \& credit and seek ways to certify local courses for international accreditation $(N=34)$

\begin{tabular}{llll}
\hline \multicolumn{1}{c}{ Items } & Mean & $S D$ & $r$ \\
\hline Recognition of international degrees and credit & 0.79 & 0.41 \\
Seek ways to certify local courses for international accreditation & 0.76 & 0.43 & $0.918^{* *}$ \\
\hline
\end{tabular}

Note: $* * p<0.01$

Twinning programs are degree course where in there is a collaboration with an international (foreign) universities at the degree level (AIPCE, 2009). Typically, students will pursue their first two years study of a degree program at host college or university and the last two years in abroad (another country); the degree is then awarded by the foreign university. An example of this is the International Dual Degrees Program of National Taiwan University (NTUOIA, 2009b). Wherein the purpose of the International Dual Degrees Program is to strengthen National Taiwan University's ties with foreign partner universities and to provide students on both sides a valuable option to broaden their academic experience (NTUOIA, 2009a).

In addition, the following items similar code of conduct for international/local student, similar policies/guideline for international/local students regarding rewards/sanctions (penalties) for accomplishments/offenses, equal opportunities for international/local faculty regarding: awards, grants, tenure, promotions, and equal opportunities for international/local student regarding: awards, grants; were all common to 25 or $74 \%$ of the responding HEIs. Similarly, the item similar policies/guidelines for international/local faculty regarding rewards/sanctions (penalties) for accomplishments/offenses were common in 24 or $71 \%$ of the responding HEIs. These results indicate that there are no special treatment with regards to foreign (international) students and faculties. Similarly, opportunities for both the local and international students and faculties alike are all equal.

Furthermore, the items foreign language admission requirement for incoming students and foreign language graduation requirement for students is common in only 14 or $41 \%$ and 21 or $62 \%$ respectively. These results indicate that Taiwan HEIs are becoming concerned with the importance of learning an additional language (English) besides the native language. Common with many countries throughout Asia, Taiwan regards English language education as a critical factor in its future. Indeed, 80\% of respondents in a public opinion survey published in January 2006 reported that they hoped that the Taiwanese government would designate the English language as the second official language (Graddol, 2006). Hence, English language education has been a compulsory part of secondary schooling (junior high school) in Taiwan since 1968. Starting 2001, English was introduced at the elementary level of Grade 5, and later on in 2005, at the elementary level of Grade 3 (GIO, 2007; Oladejo, 2005).

\subsection{Organizational Infrastructure and Resources}

Organizational infrastructure and resources indicates the availability of an internationalization supporting system. This includes physical facilities such as office space; human resources such as professionals and staff; and communication and technological resources. In many countries, internationalization activities are now recognized as highly specialized activities that requires professional staff with proper academic training and years of international education experience (Paige, 2005).

Results show that the item having an institutional committee, center, or office in place that works solely for 
the advancement of internationalization was common in 25 or $74 \%$ of the responding HEIs. This is actually the presence of a dedicated division or group of people, tasked to handle the internationalization efforts of the institution. For the least common item, around 9 or $27 \%$ of the responding HEIs mentioned that the item faculty and department committees responsible for international education are only practiced in some of the HEIs. This also coincides with the previous result in the internationalization indicator strategic planning; wherein the responding HEIs, indicated that internationalization in Taiwan's HEIs are mostly coordinated in the university levels. Although, this result indicates that the internationalization efforts are centralized in the university level administration, faculty and departmental level internationalization are also deemed important. De Wit (2002) mentioned that internationalization is becoming an integral part of HEIs, changes in the strategies are increasingly placing both the faculty and students as the center of such activities.

\subsection{Academic Offerings and Curriculum}

Academic offerings and curriculum are considered to be amongst the most important facets of HEIs' internationalization efforts. Almost all of the relevant studies reviewed mentioned the importance of internationalized academic programs. Efforts regarding the availability of professional language courses and the presence of staff responsible for internationalization curriculum development are key items in this indicator. Many scholars mentioned that the bringing an international dimension to the curriculum and teaching/learning process is a strategic priority (Bond, Qian, \& Huang, 2003; Bonfiglio, 1999; Ellingboe, 1998; Mestenhauser, 2002; Paige, 2003).

Results show that the item availability of foreign language programs is common in around 24 or $71 \%$ of the responding HEIs. This finding indicates that Taiwan's HEIs curriculum internationalization is mostly concentrated in the availability of foreign language course programs. In addition, although the following items availability of programs which are international in character like area studies, international studies, and the like and general education requirement includes courses that primarily features perspectives, issues, or events from foreign countries, which is found in only 20 or $59 \%$ and 16 or $47 \%$ of the responding HEIs respectively; these results indicate that almost half of the responding HEIs are have an internationalized curriculum.

In addition, the item gives credit to international activities like study abroad, international internships, international service opportunities, and the like was common in 27 or $79 \%$ of the responding HEIs. This result indicates that the responding HEIs gives importance to such internationalization activities, while, the rest of the items is quite low from 6 or $18 \%$ to 9 or $27 \%$ of the responding HEIs. These results indicate that there are still some items that need to be improved in order to enhance further the internationalization of the curriculum.

Lastly, the item giving scholarships and awards for graduate students to conduct research abroad, which is found in 17 or $50 \%$ of the responding HEIs, indicates that most HEIs not only encouraged their students to conduct researches (study) in another country, but most HEIs in cooperation with Taiwan's MOE gives scholarship and awards to deserving students (for example the National Science Council's Thousand Mile Horse Program). This strategy is deemed as one of the most competitive program for the local graduate students in Taiwan (NSC, 2003).

\subsection{Performance Evaluation and Accountability}

Performance evaluation and accountability is the availability of a monitoring system wherein both internal and external performance evaluations are conducted. This includes a committee involved in reporting on and making recommendations for the improvement of the institution's internationalization efforts. This indicator focuses on the importance of assessing and enhancing the quality of the institution's international dimension, which is evaluated according to their stated institutional aims and objectives (Chin \& Ching, 2009).

Results show that all of the items were common to less than forty percent of the responding HEIs; ranging from 8 or $24 \%$ to 13 or $38 \%$. These would indicate that although HEIs are undergoing frequent evaluation by the 
Apple and oranges: Comparison of Taiwan higher education institutions' internationalization

HEEACT, however, the factor regarding the internationalization of HEIs are mostly concentrated in the performance statistics, such as: qualitative and quantitative statistical analysis of scientific journal papers published by each institution, employers' satisfaction of graduates from each institution, numbers of patent received by each institution, and studies on performance of industry collaborations by each institution (HEEACT, 2009). In essence, performance evaluation and accountability tasks are seemed to be more a third-party (government) responsibility, rather than an in-campus activity.

Further analysis of the results also reveal that most member institutions of the Project to Develop First-Class International University Research Centers are correlated with the performance evaluation and accountability items, with the exception of only two items namely: designated staffs for performance monitoring and administrative committee responsible for reviewing the annual reports, making suggestions for future activities, and making suggestions for revisions of the strategic plan (for more details, please refer to table 6). These results indicate that the member institutions of the Project to Develop First-Class International University Research Centers are indeed more thorough in their internationalization efforts.

\section{Table 6}

Correlation between the member institutions of the Project to Develop First-Class International University Research Centers and performance evaluation and accountability $(N=34)$

\begin{tabular}{llll}
\hline \multicolumn{1}{c}{ Items } & Mean & SD & $r$ \\
\hline $\begin{array}{l}\text { Member institutions of the Project to Develop First-Class International } \\
\quad \text { University Research Centers }\end{array}$ & 0.18 & 0.387 & \\
A formal performance evaluation procedure is in place & & & 0.35 \\
Designated staffs for performance monitoring & 0.24 & 0.431 & 0.107 \\
Presence of internationalization performance indicators & 0.24 & 0.431 & $0.471^{* *}$ \\
Conducts internal reviews of internationalization & 0.38 & 0.493 & $0.430^{*}$ \\
Conducts external reviews of internationalization & 0.29 & 0.462 & $0.378^{*}$ \\
Scheduled performance reporting & 0.26 & 0.448 & $0.598^{* *}$ \\
Sponsoring researches regarding internationalization efforts & 0.24 & 0.431 & $0.835^{* *}$ \\
Administrative committee responsible for reviewing the annual reports, & 0.38 & 0.493 & 0.271 \\
$\quad$ making suggestions for future activities, and making suggestions & & & \\
$\quad$ for revisions of the strategic plan & & &
\end{tabular}

Note: $* * p<0.01, * p<0.05$

\subsection{Internet Presence}

Internet presence is the easy availability of important information on the institution's website. This includes links to international liaison or foreign student admission offices, bilingual information regarding important dates, fees, and news. This indicator is notably important to East Asian nations in which English is not the first language. In order to attract international students, the importance of accessible bilingual information is imperative. This indicator is the window and gateway of HEIs in Taiwan to the world (Chin \& Ching, 2009).

Results show the item link to the English version of the institution's webpage is common to 29 or $85 \%$ of the responding HEIs. This indicates that most HEIs have an English version of their websites. Regarding the other items, all of the responding HEIs claimed that these items common ranging from 11 or $32 \%$ to 23 or $68 \%$ respectively. Indicating that more than $30 \%$ of the HEIs have looked into the following items, however, many international students still mentions the lack of timely and accurate information availability (please see table 7 for more details). 


\section{Table 7}

Survey results for internet presence $(N=34)$

\begin{tabular}{|c|c|c|}
\hline Items & $n$ & $\%$ \\
\hline $\begin{array}{l}\text { Main webpage (Chinese) contains: Link to the International Office's } \\
\text { webpage }\end{array}$ & 22 & 65 \\
\hline Link to the International students' admissions webpage & 14 & 41 \\
\hline Link to the English version of the institution's webpage & 29 & 85 \\
\hline $\begin{array}{l}\text { Main webpage (English) contains: Link to the International Office's } \\
\text { webpage }\end{array}$ & 18 & 53 \\
\hline Link to the International students' admissions webpage & 19 & 56 \\
\hline $\begin{array}{l}\text { International Office's webpage contains: Contact information on } \\
\text { staffs and officers including their corresponding duties }\end{array}$ & 23 & 68 \\
\hline Directions on how to reach the school & 18 & 53 \\
\hline List of sister or partner schools & 23 & 68 \\
\hline Current internationalization news and activities & 20 & 59 \\
\hline Link to the International students' admissions webpage & 12 & 35 \\
\hline Webpage has both English and Chinese versions & 20 & 59 \\
\hline $\begin{array}{l}\text { Links to other important website like Ministry of Education, Visa } \\
\text { applications, and the like }\end{array}$ & 17 & 50 \\
\hline $\begin{array}{l}\text { International students' admissions webpage contains: Schedules of } \\
\text { important dates like opening of classes, tuition tee deadline, } \\
\text { applications dates, and the like }\end{array}$ & 14 & 41 \\
\hline Admission procedures & 17 & 50 \\
\hline Degree courses and programs & 21 & 62 \\
\hline Language studies programs & 15 & 44 \\
\hline School facilities & 16 & 47 \\
\hline Tuition fees & 15 & 44 \\
\hline Scholarship information & 17 & 50 \\
\hline $\begin{array}{l}\text { Links to other important website like Ministry of Education, Visa } \\
\text { applications, and the like }\end{array}$ & 11 & 32 \\
\hline
\end{tabular}

Further in-depth analysis of the Taiwan's HEIs websites (during the May of 2011) revealed that around 154 or $94 \%$ of the total HEIs actually have an English website. In addition, around 102 or $62 \%$ of the total HEIs have a hyperlink in the English version of their website to the international students' admissions webpage. This result indicates that most HEIs do provide admission information for international students, even though this hyperlink is found in the English version of the website. Such result is considered appropriate and quite logical with respect to an international students' point of view (please table 8 for more details).

\subsection{Faculty and Staff Development}

Faculty and staff development is the availability of support given to local personnel regarding collaboration, research, conferences, and other activities related to internationalization. Faculty involvement is the key to internationalization (Green, 2005). Faculties have the most direct contact with students and are responsible for the curriculum. In addition, the classroom remains the primary means by which to expose students to international issues, events, and cultures. This indicator measures the professional development opportunities available to faculty and staff members (Chin \& Ching, 2009). In essence, these opportunities help them increase their international skills and knowledge. 


\section{Table 8}

Analysis of Taiwan's HEIs' websites results for internet presence $(N=164)$

\begin{tabular}{lcc}
\multicolumn{1}{c}{ Items } & $n$ & $\%$ \\
\hline $\begin{array}{l}\text { Main webpage (Chinese) contains: Link to the International Office's } \\
\text { webpage }\end{array}$ & 5 & 3 \\
Link to the International students' admissions webpage & 3 & 2 \\
Link to the English version of the institution's webpage & $\mathbf{1 5 4}$ & $\mathbf{9 4}$ \\
\hline $\begin{array}{l}\text { Main webpage (English) contains: Link to the International Office's } \\
\text { webpage }\end{array}$ & 29 & $\mathbf{6 2}$ \\
Link to the International students' admissions webpage & $\mathbf{1 0 2}$ & $\mathbf{7}$ \\
No English website (link not active) & $\mathbf{1 1}$ & \\
\hline
\end{tabular}

Note: Figures in bold represents values of interest.

Results show that the item funding for inviting foreign faculties either short-term or long-term visits is common to 24 or $71 \%$ of the responding HEIs. This result indicates that the responding HEIs are highly active with regards to visiting scholars. Visiting scholars can enhances faculty collaboration and cooperation, which is deemed an important factor in internationalizing HEIs. In addition, results also show the least common item orientation for faculty with regards to all available internationalization activities with 6 or $18 \%$ of the responding HEIs. This indicates that there is a need to increase the information dissemination regarding the internationalization efforts of the institution to the faculties. With regards to the other items, the responding HEIs scored from 13 or $38 \%$ to 23 or $68 \%$ respectively. These results indicate that more than $40 \%$ of the responding HEIs do indeed practiced such items relevant to the indicator faculty and staff development.

\subsection{International Students and Scholars}

International students and scholars indicate the availability of funding, scholarships, housing, office spaces, facilities, and other supporting systems. This also includes student and language partners for international students, which helps newcomers settle easily and helps promote inter-cultural activities. The IIE definition of an international student is, one who undertakes all or part of his/her higher education experience in a country other than the home country (Project Atlas, 2004).

Recently, the cuts in public funding have forced HEIs to look abroad for financing (Green, 2005; Green \& Olson, 2003; Mok \& Tan, 2004). Under the policy of internationalization, many universities have been following aggressive strategies to attract international/foreign students, who are charged fees above the per student costs (Altbach, 2005). International students, thus helps subsidize the higher education of local students. It is sad that even some of the best universities in the world, such as Oxford and Cambridge, also seem to be adopting the same approaches, which is contrary to what they have been doing earlier, namely offering scholarships to foreign students to attract and promote the best talent (Tilak, 2005). In essence, universities are fast becoming commercialized institutions both domestically and internationally (Chang, Wu, Ching, \& Tang, 2009).

Results show that the items scholarships for international students and presence of international faculties/scholars were common to 25 or $74 \%$ and 24 or $71 \%$ of the responding HEIs. Trends in Taiwan reflect traditional East Asian patterns; in recent years the influx of international students to Taiwan has increased significantly, rising from 6,380 in 2001 to 21,005 in 2007 (Ko, 2008). Between 2001 and 2005 incoming international student enrollments from Central and South America increased 208 percent and 95 percent from European nations. Incoming students from Vietnam comprise the largest group, followed by Malaysia, Indonesia, 
Japan and the United States. Scholars attribute the rising population of incoming international students to the global popularity of Mandarin studies, the growing reputation of Taiwan universities as world class institutions, and availability of scholarships administered by the Taiwan Ministry of Education (MOE) (Ko, 2008), thus, the reason why such strategy is deemed as an important factor for the internationalization effort of Taiwan's HEIs.

\subsection{Study Abroad}

Study abroad is the availability of academic and non-academic travels. In addition, options for travel subsidies, orientation, and an in-campus facility at which to share incoming and outgoing student experiences are included. Study abroad had been active in HEIs for quite some time (de Wit, 2002), however heightened interest in recent decades has shifted traditional mobility patterns from an elitist experience characterized by scholarship or fellowship recipients to the mass movement of individuals and groups (Teichler \& Jahr, 2001).

Results show that the item student exchange agreement with partner universities abroad is common in 31 or $91 \%$ of the responding HEIs. This indicates that the responding HEIs are quite internationalized in this indicator. In fact, further analysis of all the Taiwan's HEIs websites; almost all (163 or 99\% of the total 164 HEIs in Taiwan) of the HEIs mentioned that they have exchange activities not only in the departmental levels but also in the university levels as well. Academic study abroad program is the most common in Taiwan's HEIs; wherein students' goal to study abroad is to earn academic credit. Results also show that around 22 or $65 \%$ of the responding HEIs have academic study abroad programs. One important factor that needs mentioning is the availability of scholarships, stipends, or financial supports (around 19 or $56 \%$ of the responding HEIs) for both in-coming and out-going study abroad (exchange) program students.

\subsection{Campus Life}

Campus life is the availability of academic and extracurricular activities geared towards internationalized themes. This includes the presence of a campus life office and officer and the availability of organizations or clubs with internationalized themes. This indicator focuses on making the campus life of both local and international students and scholars more accessible and comfortable (Chin \& Ching, 2009).

Results show that the item campus information, signage, billboards, and the like are written in bilingual language is common in 20 or $59 \%$ of the responding HEIs. This is actually the highest item in the indicator campus life. While the least common items are the career development center with international job placements and advising and the international leadership opportunities for students with 6 or $18 \%$ to 10 or $29 \%$ of the responding HEIs. These results indicate that the responding HEIs have been internationalizing their campus with regards to its facilities and activities. However, there is still a need for some improvement regarding the students' career and leadership development.

\subsection{Overall internationalization performance}

Internationalization is a process; a cycle of planned and spontaneous initiatives at both the program and policy levels (Knight, 2004). A process approach responds to the growing needs, resources, and priorities of the institution (Knight, 2004, 2006b). In addition, fundamental to the process approach is that both organizational structures and systems of the institution, as well as academic activities, are all together involved (Knight, 2006b). This differs from other approaches, which place more emphasis on internationalization of specific activities or outcomes (Arum \& Van de Water, 1992).

In order to measures the overall internationalization performance of an institution, the total scores within the twelve indicators where all added together. The measure of reliability as internal consistency of the survey was computed to have an overall (Lee Cronbach's (1951) coefficient alpha) alpha of 0.974, which is considered quite good (Nunnally \& Bemstein, 1994). A total of 129 items would equal to a 100\% internationalized HEI. An assumption that all of the twelve indicators and subsequent items are all equal in weights (meaning each item 
Apple and oranges: Comparison of Taiwan higher education institutions' internationalization

present is count as one point). Table 9 shows the summary of all the 34 responding HEIs. Lastly, the overall grand percentage mean was also computed to be at $52 \%$ indicating that with regards to the responding HEIs, their performance can be described as fairly internationalized.

Table 9

Overall internationalization performance $(N=129)$

\begin{tabular}{|c|c|c|c|c|c|}
\hline Institution & $n$ & $\%$ & Institution & $n$ & $\%$ \\
\hline$\# 1$ & 76 & 59 & \# 18 & 116 & 90 \\
\hline$\# 2$ & 110 & 85 & \# 19 & 27 & 21 \\
\hline$\# 3$ & 39 & 30 & \# 20 & 87 & 67 \\
\hline$\# 4$ & 105 & 81 & \# 21 & 72 & 56 \\
\hline \# 5 & 83 & 64 & \# 22 & 89 & 69 \\
\hline \# 6 & 119 & 92 & \# 23 & 91 & 71 \\
\hline \# 7 & 71 & 55 & \# 24 & 39 & 30 \\
\hline$\# 8$ & 58 & 45 & \# 25 & 32 & 25 \\
\hline$\# 9$ & 21 & 16 & \# 26 & 49 & 38 \\
\hline \# 10 & 27 & 21 & \# 27 & 42 & 33 \\
\hline \# 11 & 40 & 31 & \# 28 & 95 & 74 \\
\hline \# 12 & 26 & 20 & \# 29 & 60 & 47 \\
\hline \# 13 & 47 & 36 & \# 30 & 69 & 53 \\
\hline \# 14 & 124 & 96 & \# 31 & 57 & 44 \\
\hline \# 15 & 73 & 57 & \# 32 & 89 & 69 \\
\hline \# 16 & 77 & 60 & \# 33 & 65 & 50 \\
\hline \# 17 & 37 & 29 & \# 34 & 85 & 66 \\
\hline
\end{tabular}

Note: Figures in bold represents the top 5 internationalized HEI amongst the responding 34 HEIs.

Table 9 shows that the top five internationalized HEIs are \#14 with 124 points or $96 \%$, \#6 with 119 points or $92 \%$, \#18 with 116 points or $90 \%$, \#2 with 110 points or $85 \%$, and \#4 with 105 points or $81 \%$. While, Table 10 shows the summary of highly internationalized HEIs tabulated with regards to institution type and ownership.

With regards to Table 10, results clearly show that the leading internationalized HEIs are the national and typical (or comprehensive; which means that the institution offers various of type of course programs, including both Sciences and Social Sciences) HEIs. However, some private HEIs which are quite pioneer in the internationalization of their institutions also scored quite high. For the other institutions, normal colleges and technical colleges scored typically low. In addition, further analysis of Table 9 revealed that numerous HEIs scored quite low (from 21 to 49), as compared to the high ranking scores, their differences are almost tripled or doubled. This clearly indicates that there are extreme differences among the HEIs internationalization efforts.

\section{Conclusion}

The primary aim of this research is to measure Taiwan's HEIs internationalization using Chin and Ching (2009) internationalization indicators, namely: Institutional commitments, strategic planning, funding, institutional policy and guidelines, organizational infrastructure and resources, academic offerings and curriculum, performance evaluation and accountability, internet presence, faculty and faculty development, international students and scholars, study abroad, and campus life. Results show that with regards to current state of Taiwan's HEIs internationalization, according to the responding 34 HEIs, Taiwan's HEIs is fairly (52\%) internationalized. 


\section{Table 10}

Summary of highly internationalized HEIs $(N=129)$

\begin{tabular}{lllllr}
\hline \multicolumn{1}{c}{ Items } & Institution & $n$ & $\%$ & Rank & Over \\
\hline Overall & & & & & \\
& $\# 14$ & 124 & 96 & 1 & 1 \\
& $\# 6$ & 119 & 92 & 2 & 2 \\
& $\# 18$ & 116 & 90 & 3 & 3 \\
& $\# 2$ & 110 & 85 & 4 & 5
\end{tabular}

Private

$\begin{array}{lcccc}\# 18 & 116 & 90 & 1 & 3 \\ \# 2 & 110 & 85 & 2 & 4 \\ \# 28 & 94 & 73 & 3 & 6\end{array}$

Public

(Government)

$\begin{array}{lllll}\text { \# 14 } & 124 & 96 & 1 & 1 \\ \text { \# 6 } & 119 & 92 & 2 & 2 \\ \text { \# } 4 & 105 & 81 & 3 & 5\end{array}$

Typical

university

$\begin{array}{lllll}\# 14 & 124 & 96 & 1 & 1 \\ \# 6 & 119 & 92 & 2 & 2 \\ \# 18 & 116 & 90 & 3 & 3\end{array}$

Normal

colleges

$\begin{array}{lllll}\# 32 & 89 & 69 & 1 & 9 \\ \# 33 & 65 & 50 & 2 & 19 \\ \# 31 & 57 & 44 & 3 & 22\end{array}$

Technical/vocation

al colleges

\begin{tabular}{lllll}
$\# 5$ & 83 & 64 & 1 & 12 \\
$\# 1$ & 76 & 59 & 2 & 14 \\
$\# 7$ & 71 & 55 & 3 & 17 \\
\hline
\end{tabular}

Highly internationalized HEIs are mostly member institutions of the Project to Develop First-Class International University Research Centers. However, with the exemption of some private schools who are not members of the project, which are also highly internationalized. With regards to ownership, public HEIs ranked higher than the private HEIs; however, their differences in scores are quite minimal. With regards to institution type, typical universities are expected to be far more internationalized than the normal and technical/vocational colleges. One major reason besides the fact that typical universities are larger (infrastructure, resources, and organization), typical universities in Taiwan are mostly geared towards becoming research universities; hence, internationalization efforts would be more deliberate and evident. 
Apple and oranges: Comparison of Taiwan higher education institutions' internationalization

Generally, Taiwan's HEIs focus much of their internationalization efforts on the signing of MOUs and MOAs (sister/partners schools), which leads to the different exchange programs such as faculty and student exchanges, and study abroad programs. Eventually, the actual presence of international students and scholars has lead to the uplifting of an atmosphere of internalization in the campus. Furthermore, improving the curriculum and the availability of foreign language course program are also seen as a goal of internationalization. Many HEIs have established Mandarin Chinese Language centers, which recently has gained much popularity and is seen as a competitive advantage and a pull factor for international students.

Taiwan's HEIs internationalization is mostly concentrated in the university level, although exchanges are being done and coordinated in the departmental levels (student and faculty exchange activities; including study abroad), there is still a need to improve the internationalization efforts in the department levels; more so in the areas of international curriculum and course developments, and international activities. Similarly, there is also a need to improve the HEIs' websites. Although almost all HEIs have English versions of their websites, however, direct hyperlinks to their international office and international students' admissions page are rarely found in the Chinese version of the website (main page).

Internationalization in Taiwan's HEIs is also demonstrated by the presence of the campus international affairs department (center/office), which has become a focal point for facilitating the internationalization efforts of the institution. Some of the common activities performed by the international offices include: providing support and coordination to departmental internationalization efforts, signings of MOUs and MOAs with partner institutions, raising awareness of opportunities for internationalization, and the coordination of student and faculty exchange activities (including study abroad).

Given that the Taiwan HEIs' internationalization rationales is to prepare graduates who are internationally knowledgeable and inter-culturally competent, therefore institutions clearly values the contribution of internationalization toward academic goals. In addition, the internationalization of the curriculum offerings does not only attract international students, but it also makes the teaching/learning process more relevant for international students as well. Subsequently, it raises the institution's profile on the global stage of higher education. More importantly, an internationalized curriculum provides an avenue for the local Taiwanese students to develop their global perspectives and skills without leaving their home country.

Internationalization of HEIs in Taiwan is still in its early stages, hence, HEIs are mostly concentrated in the development within the local arenas; plans for the expansion of foreign branches are still in the minimal. Furthermore, although the participants of this study are only the 34 HEIs; results can be seen as a perspective on the efforts being taken by Taiwanese universities towards internationalization. Lastly, with the inclusion of the term internationalization in the institutional mission vision and objectives; this clearly indicates that the Taiwan's HEIs internationalization has already been acknowledged to be a part the institution's efforts to fulfill its primary functions.

Note. HEIs included in the study are the following: TTU, CMU, CUMT, CTUST, YPU, SHU, TMU, CSU, MCUT, MDU, THU, CGU, NTCNC, MU, NUTN, NCTU, NCKU, NFU, NDHU, NPUST, NPUE, NCCU, NKNU, NTHU, NCUE, NYMU, NCNU, TKU, MHCHCM, HWH, ISU, MCU, PU, and APIC.

NOTE: Earlier versions of this paper have been presented at the 2009 Southeast Asian Psychology Conference in Sabah, Malaysia and at the 2010 Annual Conference of the Comparative and International Education Society of the United States in Chicago.

Acknowledgement: This paper is part of a longer Doctoral Dissertation accomplished in 2009 for the Graduate Program of Education at the National ChengChi University in Taiwan. 


\section{References:}

AIPCE. (2009). Twinning program and career campus. Retrieved June 6, 2009, from http://www.careercampus.info/twinningprogram.htm

Altbach, P. G. (2005). Globalization and the university: Myths and realities in an unequal world. In The NEA 2005 Almanac of Higher Education (pp. 63-74). Washington, DC: National Education Association.

Altbach, P. G., \& Knight, J. (2007). The internationalization of higher education: Motivations and realities. Journal of Studies in International Education, 11(3/4), 290-305. $<$ http://dx.doi.org/10.1177/1028315307303542>

Arum, S., \& Van de Water, J. (1992). The need for a definition of international education in U.S. universities. In C. Klasek (Ed.), Bridges to the future: strategies for internationalizing higher education (pp. 191-203). Carbondale, IL, USA: Association of International Education Administrators.

Axinn, W. G., Fricke, T. E., \& Thornton, A. (1991). The micro demographic community-study approach: Improving survey data by integrating the ethnographic method. Sociological Methods and Research, 20(2), 187-217. <http://dx.doi.org/10.1177/0049124191020002001>

Bond, S., Qian, J., \& Huang, J. (2003). The role of faculty in internationalizing the undergraduate curriculum and classroom experience (Vol. 8). Ottawa, ON: Canadian Bureau for International Education.

Bonfiglio, O. (1999). The difficulties of internationalizing the American undergraduate curriculum. Journal of Studies in International Education, 3(2), 3-18. <http://dx.doi.org/10.1177/102831539900300202>

Chang, D. F., Wu, C. T., Ching, G. S., \& Tang, C. W. (2009). An evaluation of the dynamics of the plan to develop first-class universities and top-level research centers in Taiwan. Asia Pacific Education Review, 10(1), 47-57. <http://dx.doi.org/10.1007/s12564-009-9010-7>

Chen, L. Y. (2007). Implications of competing values framework for developing internationalization indicators in higher education evaluation plan [In Chinese]. Journal of Educational Administration and Evaluation, $3,1-18$.

Chin, J. M. C., \& Ching, G. S. (2009). Trends and indicators of Taiwan's higher education internationalization. The Asia-Pacific Education Researcher, 18(2), 185-203. <http://dx.doi.org/10.3860/taper.v18i2.1322>

Chou, C. P., \& Ho, A. H. (2007). Schooling in Taiwan. In G. Postinglione (Ed.), Going to school in East Asia. New York: Greenwood.

Cronbach, L. J. (1951). Coefficient alpha and the internal structure of tests. Psychometrika, 16, 197-334. $<$ http://dx.doi.org/10.1007/BF02310555>

Daly, A. J., \& Barker, M. C. (2005). Australian and New Zealand university students' participation in international exchange programs. Journal of Studies in International Education, 9(1), 26-41. $<$ http://dx.doi.org/10.1177/1028315304271479>

Davies, J. L. (1995). University strategies for internationalisation in different institutional and cultural settings: A conceptual framework. In P. Blok (Ed.), Policy and policy implementation in internationalisation of higher education. Amsterdam: European Association for International Education.

Davies, J. L. (1997). A European agenda for change for higher education in the XXIst century: Comparative analysis of twenty institutional case studies CRE-action, 111, 47-92.

de Wit, H. (2002). Internationalization of higher education in the United States of America and Europe. Westport, CT: Greenwood Publishing.

Ellingboe, B. J. (1998). Divisional strategies to internationalize a campus portrait: Results, resistance, and recommendations from a case study at a US university. In J. A. Mestenhauser \& B. J. Ellingboe (Eds.), Reforming the higher education curriculum: Internationalizing the campus (pp. 198-228). Washington, DC: American Council on Education.

GIO. (2007). Mainstream education. Retrieved August 4, 2008, from http://www.gio.gov.tw/ct.asp?xItem=32865\&ctNode $=2598$

Graddol, D. (2006). English next. Retrieved September 2, 2008, from http://www.britishcouncil.org/learning-research-english-next.pdf

Green, M. F. (2005). Measuring internationalization at research universities. Washington, DC: American Council on Education.

Green, M. F., Luu, D. T., \& Burris, B. (2008). Mapping internationalization on US Campuses: 2008 Edition. Washington, DC: American Council on Education.

Green, M. F., \& Olson, C. (2003). Internationalizing the campus: A user's guide. Washington, DC: American Council on Education.

Hayward, F. M. (2000). Internationalization of US higher education: Preliminary status report 2000. 
Apple and oranges: Comparison of Taiwan higher education institutions' internationalization Washington, DC: American Council of Education.

HEDDA. (2007). Private funding of higher education increases around the globe. Retrieved June 4, 2009, from http://uv-blog.uio.no/mt/flexlearn/2007/08/private-funding-of-higher-educ.html

HEEACT. (2009). Introduction on performance statistics. Retrieved June 7, 2009, from http://www.heeact.edu.tw/ct.asp?xItem $=3576 \& \mathrm{CtNode}=674 \& \mathrm{mp}=4$

Johnson, B., \& Christensen, L. (2008). Educational research - Quantitative, qualitative, and mixed approaches (3rd ed.). Thousand Oaks, California: Sage Publications.

Kelo, M. (Ed.). (2008). Beyond 2010. Priorities and challenges for higher education in the next decade. Bonn: Lemmens.

Kingsbury, A. (2007, March 12). Special report - The measure of learning. U.S. News \& World Report.

Knight, J. (2003). Internationalization of higher education practices and priorities: 2003 IAU survey report. Paris, France: International Association of Universities.

Knight, J. (2004). Internationalization remodeled: Definition, approaches, and rationales. Journal of Studies in International Education, 8(1), 5-31. <http://dx.doi.org/10.1177/1028315303260832>

Knight, J. (2005). Internationalization of higher education: New directions, new challenges. The 2005 IAU global survey report. Paris, France: International Association of Universities.

Knight, J. (2006a). IAU 2005 internationalization survey: Preliminary findings report. Paris, France: International Association of Universities.

Knight, J. (2006b). Internationalization: Concepts, complexities and challenges. In J. Forest \& P. G. Altbach (Eds.), International handbook of higher education. Netherlands: Springer.

Ko, S. L. (2008, February 12). International students in Taiwan at an all-time high. China Times, p. 3, from http://www.taipeitimes.com/News/taiwan/archives/2008/02/12/2003400913

Lu, M. L. (2003). The making of world class research universities in an age of globalization - Components and challenges. Retrieved July 29, 2008, from http://english.moe.gov.tw/ct.asp?xItem=292\&ctNode=369\&mp=11

Marden, P. G., \& Engerman, D. C. (1992). International interest: Liberal arts colleges take the high road. Educational Record, 73(2), 42-46.

Mestenhauser, J. A. (2002). In search of a comprehensive approach to international education: A systems perspective. In W. Grünzweig \& N. Rinehart (Eds.), Rocking in red square: Critical approaches to international education in the age of cyberculture. Muenster, Germany: LIT Verlag.

Miles, M., \& Huberman, M. (1994). Qualitative data analysis (2nd ed.). Beverly Hills, CA: Sage.

MOE. (2006a). Education in Taiwan 2006. Retrieved June 6, 2009, from http://english.moe.gov.tw/public/Attachment/692014352071.pdf

MOE. (2006b). Plan to develop first-class universities and top-level research centers. Retrieved July 3, 2008, from http://english.moe.gov.tw/ct.asp?xItem=7131\&ctNode $=505 \& \mathrm{mp}=1$

MOE. (2008a). 2008 Educational statistical indicators. Retrieved May 25, 2008, from http://english.moe.gov.tw/lp.asp?ctNode $=816 \& \mathrm{CtUnit}=507 \&$ BaseDSD=7\&mp $=1$

MOE. (2008b). An educational overview. Retrieved May 25, 2008, from http://english.moe.gov.tw/ct.asp?xItem $=4133 \& \mathrm{CtNode}=2003 \& \mathrm{mp}=1$

Mok, K. H. (2003). Similar trends, diverse agendas: Higher education reforms in East Asia. Globalisation, Societies and Education, 1(2), 201-221. <http://dx.doi.org/10.1080/14767720303910>

Mok, K. H. (2006, January 13-14). Questing for internationalization of universities in East Asia: Critical reflections. Paper presented at the International symposium, Osaka University, Japan.

Mok, K. H., Deem, R., \& Lucas, L. (2008, February 23). Transforming higher education in whose image? Exploring the concept of the "World-Cass" university in Europe and Asia. Paper presented at the CERC Annual Conference 2008, Hong Kong Institute of Education.

Mok, K. H., \& Tan, J. (2004). Globalization and marketization in education: A comparative analysis of Hong Kong and Singapore. UK: Edward Elgar Publishers.

Neave, G. (1992a). Institutional management of higher education: Trends, needs and strategies for co-operation. Unpublished International Association of Universities document for UNESCO, Paris.

Neave, G. (1992b). Managing higher education international co-operation: Strategies and solutions. Unpublished Reference document for UNESCO, Paris.

Neubauer, D. (2007). Globalization and education - Characteristics, dynamics, implications. In P. D. Hershock, M. Mason \& J. N. Hawkins (Eds.), Changing education - Leadership innovation and development in a globalizing Asia Pacific (pp. 29-62). Hong Kong: Comparative Education Research Centre - Springer.

NSC. (2003). Thousand mile horse program [In Chinese]. Retrieved June 7, 2009, from http://www.nsc.gov.tw/tech1/ct.asp?xItem=1765\&ctNode=794

NTUOIA. (2009a). Guidelines for international dual degrees program. Retrieved June 7, 2009, from 
Chin, J. M. C., Wu, C. T., \& Ching, G. S.

http://www.oia.ntu.edu.tw/Chinese/overseadegree/96_in_dual_en3.asp

NTUOIA. (2009b). Office of international affairs incoming international dual degrees program. Retrieved June 6, 2009, from http://www.oia.ntu.edu.tw/Chinese/overseadegree/96_in_dual_en1.asp

Nunnally, J. C., \& Bemstein, L. H. (1994). Psychometric theory. New York: McGraw-Hill.

Oladejo, J. (2005). Parents' attitudes towards bilingual education policy in Taiwan. Unpublished Masteral thesis, National Kaohsiung Normal University, Kaohsiung.

Paige, R. M. (2003). The American case: The university of Minnesota. Journal of Studies in International Education, 7, 52-63. <http://dx.doi.org/10.1177/1028315302250180>

Paige, R. M. (2005). Internationalization of Higher Education: Performance Assessment and Indicators. Nagoya Journal of Higher Education, 5, 99-122.

Project Atlas. (2004). Atlas of student mobility. Retrieved September 20, 2008, from http://www.atlas.iienetwork.org/

Shutina, R. (2008). An investigation of the role that the nation's six major higher-education associations have played in the internationalization of American higher education during the last decade (1996-2006). Unpublished $\mathrm{Ph}$. D. dissertation, University of Toledo, Toledo, $\mathrm{OH}$.

Siaya, L., \& Hayward, F. M. (2003). Mapping internationalization on U.S. campuses. Washington, DC: American Council on Education.

Song, M. M., \& Tai, H. H. (2007). Taiwan's responses to globalisation: Internationalisation and questing for world class. Asia Pacific Journal of Education, 27(3), 323-340. $<\underline{\text { http://dx.doi.org/10.1080/02188790701594067> }}$

Teichler, U., \& Jahr, V. (2001). Mobility during the course of study and after. European Journal of Education, 36(4), 443-458. <http://dx.doi.org/10.1111/1467-3435.00081>

Tilak, J. B. G. (2005). Global trends in funding higher education. Retrieved June 4, 2009, from http://www.bc.edu/bc_org/avp/soe/cihe/newsletter/Number42/p5_Tilak.htm

Welch, A. (2004). Accountability or accountability? Governance and university evaluation systems in an era of performativity. COE Publication Series, 11, 117-138. 